\title{
BATIK CIAMISAN \\ DI Imbanagara kabupaten GIAmIs \\ (Sebuah Kajian Nilai Budaya)
}

\author{
Batik Ciamisan in Imbanagara, Regency of Ciamis \\ (A Study of Cultural Valuaes)
}

\author{
Oleh Lina Herlinawati \\ Balai Pelestarian Nilai Budaya Bandung \\ Jl. Cinambo No. 136 Ujungberung - Bandung \\ Email: linaemul000@yahoo.com
}

\begin{abstract}
Abstrak
Perkembangan industri tekstil yang semakin maju mengakibatkan keberadaan batik tradisional kini mulai surut, termasuk yang dialami batik tulis Ciamisan. Kerajinan tersebut merupakan aset kerajinan tradisional yang perlu dipertahankan agar tidak punah. Untuk itu dilakukan upaya pelestarian dengan melakukan penelitian perihal kajian nilai budaya pada batik tulis Ciamisan tersebut di Dusun Ciwahangan Kecamatan Imbanagara Kabupaten Ciamis, sebagai satu-satunya daerah yang masih terdapat aktivitas kerajinan batik tulis Ciamisan. Penelitian tersebut bersifat deskriptif analisis dengan pendekatan kualitatif. Data yang dikumpulkan terdiri atas data primer dan data sekunder. Data sekunder diperoleh dari studi pustaka, dengan cara mempelajari arsip-arsip literatur yang menunjang pelaksanaan penelitian. Data primer diperoleh dengan cara pengamatan, wawancara, dan pemotretan di daerah objek penelitian. Hasil penelitian menunjukkan bahwa dengan perjalanan keberadaan batik tulis Ciamisan dari awal perkembangannya hingga kini dapat dikatakan, corak batik tulis Ciamisan tidak memiliki makna filosofi perlambang, nilai sakral, atau menunjukkan status sosial tertentu. Namun penciptaan motif atau ragam hias batiknya lebih ditekankan pada ungkapan kesederhanaan untuk memenuhi kebutuhan sandang, sinjang 'kain' bagi masyarakat. Nilai filosofi kesederhanaannya itu terlihat dalam bentuk-bentuk motif yang terinspirasi dari alam sekitar dan kejadian sehari-hari. Selanjutnya teknik membuat batik berkembang, tidak hanya batik tulis saja, muncul batik cap, batik sablon, batik painting/lukis, dan batik printing. Demikian pula dengan motif batiknya, para perajin tidak hanya menghidupkan kembali motif-motif lama batik Ciamisan, juga meluncurkan motif baru hasil inovasi.
\end{abstract}

Kata Kunci: batik tulis, Ciamisan, kesederhanaan. 


\begin{abstract}
The progress in the development of textile industry has made batik tulis or traditional batik (hand-drawn batik) less popular, including batik Ciamisan. This kind of craftsmanship actually must be preserved. Therefore, in order to do that the author conducted a research on cultural values of batik tulis Ciamisan which took place in Dusun (village) Ciwahangan, Kecamatan (district) Imbanagara, Kabupaten (regency) Ciamis. This is a descriptive analytical study with qualitative approach. Data were collected either primarily (by observation, interviews, and taking photographs) or secondarily (bibliographic studies). The result shows that motifs of batik Ciamisan do not have symbolic nor sacred values. They do not reflect certain social status as well. Even since its very beginning until its development today. The creation of motifs is simply stressed on fulfilling the need of cloth for apparel (sinjang) with simple designs inspired from the mother nature and everyday life. The technique varies from traditional (batik tulis), stamping (batik cap), painting and printing. The craftsmen also have innovated new motifs.
\end{abstract}

Keywords: batik tulis, Ciamisan, simplicity

\section{A. PENDAHULUAN}

Dewasa ini, batik tulis Ciamisan nyaris tinggal nama. Kebesarannya tenggelam dalam kemajuan zaman, tersingkirkan oleh kemajuan industri tekstil yang serba cetak, termasuk industri batik cetak (printing). Tak hanya itu, akibat bencana alam Gunung Galunggung dan situasi perekonomian yang tidak stabil akibat krisis moneter, juga tidak mendukung keberadaan para pengusaha batik tulis, sehingga banyak yang gulung tikar. Pada akhirnya, banyak perajin batik tulis Ciamisan yang memilih untuk berhenti. Hingga memasuki tahun 2004, perajin batik Ciamisan yang masih eksis tinggal seorang dari ribuan perajin batik Ciamisan yang pernah ada, yaitu H. Otong Kartiman (69 thn), yang memiliki pabrik batik dengan bendera Bintang Pusaka di rumahnya, di Dusun Ciwahangan Kecamatan Imbanagara.

Mengingat kondisi demikian, timbul kekhawatiran akan hilangnya aset budaya tersebut jika tidak dilakukan upaya pelestarian sesegera mungkin. Salah satu bentuk upaya pelestarian adalah dengan melakukan penelitian perihal kajian nilai budaya pada batik tulis Ciamisan tersebut, dengan judul Di Balik Kesederhanaan Batik Ciamisan di Imbanagara. Adapun lokasi penelitian dilakukan di Dusun Ciwahangan Kecamatan Imbanagara Kabupaten Ciamis, sebagai satu-satunya daerah yang masih terdapat aktivitas kerajinan batik tulis Ciamisan.

Upaya penyelamatan aset budaya batik tulis Ciamisan tersebut, terlebih batik telah ditetapkan UNESCO sebagai The World Cultural Heritage of Humanity from Indonesia. Pengukuhan tradisi batik sebagai salah satu budaya warisan dunia asli Indonesia itu dilaksanakan pada tanggal 2 Oktober 2009 di Abu Dhabi Uni Emirt.

Penelitian ini berupaya untuk menjawab kekhawatiran akan hilangnya Batik Ciamisan sebagai aset budaya, jika tidak dilakukan upaya pelestarian sesegera mungkin. Adapun tujuan yang ingin dicapai melalui kajian ini adalah berupaya untuk menggali dan menemukenali nilainilai budaya yang terkandung dalam batik Ciamisan. Selanjutnya hasil penelitian akan dijadikan informasi dan publikasi tentang batik Ciamisan; sekaligus mem bantu pemerintah dalam upaya pelestarian 
khasanah hasil budaya yang hampir punah, terutama yang dapat menjadi aset daerah bersangkutan; serta meningkatkan perhatian dan apresiasi masyarakat terhadap khasanah budaya yang mempunyai potensi, terutama dalam sektor sosial ekonomi masyarakat.

Materi yang menjadi sasaran utama dalam penelitian ini adalah berbagai hal yang berkaitan dengan sumber daya manusia yang bekerja di sentra batik, batik sebagai produk, corak dan motif batik, serta hal-hal yang berkaitan dengan proses pembuatan batik. Lokasi penelitian adalah di Dusun Ciwahangan Desa Imbanagara Kecamatan Ciamis Kabupaten Ciamis.

Penelitian yang digunakan bersifat deskriptif dengan metode kualitatif, yaitu suatu cara yang digunakan untuk menyelidiki dan memecahkan masalah yang tidak terbatas pada pengumpulan dan penyusunan data saja, tetapi meliputi analisis dan interpretasi data sampai pada kesimpulan yang didasarkan atas penelitian.

Data yang dikumpulkan adalah data primer dan sekunder. Data sekunder, penulis peroleh dari studi pustaka, dengan cara mempelajari arsip-arsip literatur yang menunjang pelaksanaan penelitian. Adapun data primer, penulis peroleh dengan cara pengamatan, wawancara, dan pemotretan di daerah objek penelitian.

\section{B. HASIL DAN BAHASAN}

\section{Gambaran Lokasi}

Desa Imbanagara, sebagai tempat perajin batik Ciamisan yang masih bertahan hingga sekarang, secara administrasi termasuk ke dalam wilayah Kecamatan Ciamis. Secara geografis Kecamatan Ciamis terletak di antara \pm $108^{\circ} 20^{\prime}-108^{\circ} 40^{\prime}$ Bujur Timur dan 740'20" Lintang Selatan, dengan ketinggian $\pm 199 \mathrm{~m}$ dari permukaan laut.

Kecamatan Ciamis merupakan pusat pemerintah Kabupaten Ciamis dan dalam peta wilayah Kabupaten Ciamis berada pada posisi tengah atau dikenal dengan sebutan wilayah utara, dengan batas-batasnya sebagai berikut: sebelah utara berbatasan dengan Kecamatan Baregbeg dan Kecamatan Sadananya; sebelah timur berbatasan dengan Kecamatan Cijeungjing; sebelah selatan berbatasan dengan Kabupaten Tasikmalaya; dan sebelah barat berbatasan dengan Kecamatan Cikoneng.

Kecamatan Ciamis terdiri atas beberapa desa dan kelurahan, yaitu: Desa Cisadap, Imbanagara Raya, Imbanagara, Panyingkiran, Pawindan; dan Kelurahan Benteng, Ciamis, Cigembor, Kertasari, Linggasari, Maleber, dan Sindanglaya.

Jarak pusat Pemerintahan kecamatan ke desa/kelurahan terjauh adalah ke Desa Imbanagara dan Desa Cisadap, yakni $8 \mathrm{~km}$ arah barat. Jarak dari kota Kecamatan Ciamis ke beberapa pusat kota/daerah: ke Pusat Kota Ciamis (ibukota Kabupaten Ciamis) $2 \mathrm{~km}$ dan ke Bandung (ibukota provinsi) $122 \mathrm{~km}$.

Jumlah penduduk Kecamatan Ciamis menurut data pada Monografi Kecamatan Ciamis tahun 2010, tercatat sebanyak 93.217 jiwa yang terangkum dalam 29.527 KK, terdiri atas laki-laki 46.956 jiwa atau $50,37 \%$ dan perempuan 46.261 jiwa atau 49,63\% dari jumlah penduduk secara keseluruhan.

Kemudian berdasarkan mata pencaharian utama yang digeluti masyarakatnya, komposisinya adalah pedagang sebanyak 6.692 orang, PNS sebanyak 5.013 orang, petani pemilik tanah sebanyak 4.904 orang, pengangkutan sebanyak 1.047 orang, buruh industri sebanyak 839 orang, pengrajin/industri kecil 632 orang, ABRI/POLRI sebanyak 493, dan buruh bangunan sebanyak 341 orang.

Sarana pendidikan merupakan salah satu aspek penting dalam meningkatkan kualitas manusia, yang dapat meningkatkan pembangunan guna kemajuan masyarakat. Jumlah sekolah yang ada di Kecamatan Ciamis cukup lengkap, mulai dari tingkat TK hingga SLTA. Hanya untuk melanjutkan ke jenjang yang lebih tinggi, seperti ke akademi atau perguruan 
tinggi, warga harus bersekolah keluar Kecamatan Ciamis.

Mayoritas penduduk Kecamatan Ciamis beragama Islam. Sisanya beragama Katolik, Protestan, Hindu, Budha, dan Aliran Kepercayaan kepada Tuhan YME. Untuk memenuhi kebutuhan beribadahnya, pemeluk agama Islam memiliki sarana peribadatan berupa masjid sebanyak 131 buah dan surau/mushola sebanyak 373 buah.

\section{Pengertian Batik}

Batik (atau kata Batik) berasal dari bahasa Jawa amba yang berarti menulis dan nitik yang berarti memberi titik. Kata batik sendiri merujuk pada teknik pembuatan corak - menggunakan canting atau cap - dan pencelupan kain dengan menggunakan bahan perintang warna corak "malam" (wax) yang diaplikasikan di atas kain, sehingga menahan masuknya bahan pewarna. Dalam bahasa Inggris teknik ini dikenal dengan istilah wax-resist dyeing. Jadi kain batik adalah kain yang memiliki ragam hias atau corak yang dibuat dengan canting dan cap dengan menggunakan malam sebagai bahan perintang warna. Teknik ini hanya bisa diterapkan di atas bahan yang terbuat dari serat alami seperti katun, sutra, wol dan tidak bisa diterapkan di atas kain dengan serat buatan (polyester). Kain yang pembuatan corak dan pewarnaannya tidak menggunakan teknik ini dikenal dengan kain bercorak batik - biasanya dibuat dalam skala industri dengan teknik cetak (print) - bukan kain batik.

Batik adalah kerajinan yang memiliki nilai seni tinggi dan telah menjadi bagian dari budaya Indonesia (khususnya Jawa) sejak lama. Perempuanperempuan Jawa di masa lampau menjadikan keterampilan mereka dalam membatik sebagai mata pencaharian, sehingga di masa lalu pekerjaan membatik adalah pekerjaan eksklusif perempuan sampai ditemukannya "Batik Cap" yang memungkinkan masuknya laki-laki ke dalam bidang ini. Ada beberapa pengecualian bagi fenomena ini, yaitu batik pesisir yang memiliki garis maskulin seperti yang bisa dilihat pada corak "Mega Mendung", dimana di beberapa daerah pesisir pekerjaan membatik adalah lazim bagi kaum lelaki.

Ragam corak dan warna batik dipengaruhi oleh berbagai pengaruh asing. Awalnya, batik memiliki ragam corak dan warna yang terbatas, dan beberapa corak hanya boleh dipakai oleh kalangan tertentu. Namun batik pesisir menyerap berbagai pengaruh luar, seperti para pedagang asing dan juga pada akhirnya, para penjajah. Warna-warna cerah seperti merah dipopulerkan oleh Tionghoa, yang juga mempopulerkan corak phoenix. Bangsa penjajah Eropa juga mengambil minat pada batik, dan hasilnya adalah corak bunga-bungaan yang sebelumnya tidak dikenal (seperti bunga tulip) dan juga benda-benda yang dibawa oleh penjajah (gedung atau kereta kuda), termasuk juga warna-warna kesukaan mereka seperti warna biru. Batik tradisional tetap mempertahankan coraknya, dan masih dipakai dalam upacara-upacara adat, karena biasanya masing-masing corak memiliki perlambangan masing-masing (http://id.wikipedia.org/wiki/Batik).

Teknik membatik telah dikenal sejak ribuan tahun yang silam. Tidak ada keterangan sejarah yang cukup jelas tentang asal-usul batik. Ada yang menduga teknik ini berasal dari bangsa Sumeria, kemudian dikembangkan di Jawa setelah dibawa oleh para pedagang India. Saat ini batik bisa ditemukan di banyak negara seperti Indonesia, Malaysia, Thailand, India, Sri Lanka, dan Iran. Selain di Asia, batik juga sangat populer di beberapa negara di Benua Afrika. Walaupun demikian, batik yang sangat terkenal di dunia adalah batik yang berasal dari Indonesia, terutama dari Jawa.

Tradisi membatik pada mulanya merupakan tradisi yang turun temurun, sehingga kadang kala suatu motif dapat dikenali berasal dari batik keluarga tertentu. Beberapa motif batik dapat menunjukkan status seseorang. Bahkan 
sampai saat ini, beberapa motif batik tradisional hanya dipakai oleh keluarga keraton Yogyakarta dan Surakarta.

Pada awalnya semua batik dibuat dengan metode batik tulis, menggunakan canting tulis yang dikerjakan oleh perempuan-perempuan di Jawa. Pada abad 19, muncullah batik cap yang dibuat oleh para lelaki dengan menggunakan cap dari tembaga yang berat. Pada proses membuat batik cap, pekerjaan 'kotor' seperti mengatur warna, pencelupan sampai proses cap dikerjakan oleh lelaki, sementara pembuatan dengan canting tulis dikerjakan secara halus oleh perempuan. Perkembangan selanjutnya muncul teknik membuat batik sablon, batik painting/lukis, dan batik printing.

Batik tulis adalah peninggalan teknik pembuatan batik yang paling tua, yaitu pembuatan batik dengan menghias kain dengan tekstur dan corak batik menggunakan canting untuk penutup atau pelindung terhadap zat warna. Proses pembuatan batik tulis membutuhkan ketelatenan tingkat tinggi, karena dikerjakan dengan tangan dan langsung melukiskan corak atau motif di selembar kain. Untuk membuat batik tulis membutuhkan proses yang sangat lama, biasanya 2-3 bulan.

Batik cap yaitu batik yang pembuatan motifnya menggunakan stempel. Cap ini biasanya terbuat dari tembaga yang telah digambar pola dan dibubuhi malam (cairan lilin panas). Batik sablon adalah batik yang motifnya dicetak dengan klise/hasil print. Pada proses batik ini, pola telah di-print di atas alat sablon, sehingga pembatikan dan pewarnaan biasa dilakukan secara langsung. Jadi, proses batik dapat diselesaikan tanpa menggunakan lilin malam serta canting. Dengan demikian, proses hanya akan dan tentu saja memerlukan waktu yang lebih cepat dibanding pada proses batik tulis dan batik cap.

Batik painting/lukis yaitu batik yang dibuat tanpa pola, tetapi langsung meramu warna di atas kain putih.
Membuat batik lukis juga membutuhkan kesabaran dalam melukis berbagai corak dan menghasilkan hasil berbeda di setiap lembar kainnya. Batik printing yaitu batik yang penggambarannya menggunakan mesin. Jenis batik ini dapat diproduksi dalam jumlah besar karena menggunakan mesin modern. Kemunculan batik printing dipertanyakan oleh kelompok seniman dan pengrajin batik karena dianggap merusak tatanan dalam seni batik, sehingga mereka lebih suka menyebutnya kain bermotif batik.

Belakangan muncul perkembangan baru pada batik print, dengan adanya metode print malam. Metode ini dapat dikatakan perpaduan antara sablon dan batik. Pada print malam, materi yang di print-kan pada kain adalah malam (lilin) dan bukan pasta seperti batik print konvensional. Setelah malam menempel, kemudian kain tersebut diproses melalui pencelupan seperti pembuatan batik pada umumnya.

\section{Sejarah Batik Ciamisan}

Tradisi batik sudah ada di Indonesia sejak masa prasejarah. Hal itu diungkapkan oleh Hasanuddin (2001), bahwa sekalipun tidak mungkin ditemukan fisik batik sebagai bukti arkeologi tentang keberadaannya pada masa silam, tetapi bukti sejarah tentang teknik rintang warna, ragam hias dekoratif, simbolik, keseimbangan dinamis yang menjiwai bentuk batik sudah dikenal pada masa prasejarah. Hal itu terbukti dari temuan arkeologi berupa arca di dalam Candi Ngrimbi dekat Jombang, yang menggambarkan sosok Raden Wijaya, raja pertama Majapahit (memerintah 1294 1309). Sosok Raden Wijaya memakai kain berhias kawung dengan teknik batik.

Adapun di Ciamis, batik dikenal sekitar abad ke-19 setelah usainya peperangan Diponegoro. Pada saat itu para pengikut Diponegoro banyak yang meninggalkan Yogyakarta, menuju ke selatan. Sebagian ada yang menetap di daerah Banyumas; sebagian lagi ada yang 
meneruskan perjalanan ke selatan dan menetap di Ciamis serta Tasikmalaya sekarang. Mereka merantau dengan keluarganya, kemudian di tempat baru mereka menetap dan menjadi penduduk di sana. Mereka pun melanjutkan tata cara hidup dan pekerjaannya, termasuk kaum wanitanya yang sebagian ada yang ahli dalam pembatikan.

Membatik adalah pekerjaan kerajinan rumah tangga bagi kaum wanita di Yogyakarta pada saat itu. Lama kelamaan jenis pekerjaan itu bisa berkembang pada penduduk sekitarnya di tempat baru, akibat adanya pergaulan sehari-hari atau hubungan keluarga. Khususnya kaum perempuan yang membutuhkan sandang berupa sinjang/samping 'kain' untuk pemakaian sehari-hari. Bahan-bahan yang dipakai adalah kain hasil tenunan sendiri dan bahan catnya dibuat dari pohon seperti: mengkudu, tarum, dan sebagainya. Mengkudu (Morinda citrifolia LINN) adalah nama pohon yang kulitnya dibuat cat merah untuk mewarnai kain batik; sedangkan tarum (W. indigoplant) yaitu nama tanaman yang daunnya kecil-kecil, dan air perasan daunnya digunakan untuk mencelup. Selanjutnya hingga awal abad ke-20 pembatikan di Ciamis berkembang sedikit demi sedikit, dari kebutuhan sendiri menjadi produksi pasaran.

Dari uraian di atas, tidaklah heran jika dikatakan motif batik Ciamis adalah campuran dari batik Jawa Tengah dan pengaruh motif dan warna dari Garut. Demikian, Ciamis Seperti halnya Tasikmalaya dan Garut memiliki tradisi turun temurun dalam sejarah kerajinan batik. Mulai adanya tradisi batik tersebut selain di atas, ada yang menyebutkan sudah ada sejak Kerajaan Galuh berjaya. Akan tetapi, yang pasti, ini sudah berlangsung sejak beberapa abad silam.

Walaupun secara geografi, antara Ciamis, Tasikmalaya dan Garut merupakan daerah yang berdekatan dan menjadi bagian dari Tatar Priangan, dalam tradisi kerajinan batik, ketiga daerah tersebut memiliki karakter dan corak batik yang berbeda.

Batik Garut, yang dalam kamus perbatikan lebih populer disebut batik Garutan lebih menonjolkan penggunaan warna krem dengan motif lereng (rengreng). Adapun tradisi batik Tasikmalaya atau batik Tasikan lebih natural dengan pilihan warna dominan merah bata dan motif burung serta kupukupu menjadi pilihan.

Akan halnya warna batik Ciamisan lebih sederhana dari batik Garutan dan Tasikan. Warna hitam dan putih begitu menonjol dengan paduan hitam dan coklat (saga). Kemudian pilihan motif daun dan parang rusak menjadi pilihan utama. Ada yang menyebutnya batik Ciamisan ini sebagai batik sarian dengan corak tidak terlalu ramai, simpel, namun elegan.

Batik Ciamisan yang tampil sederhana tapi penuh wibawa tersebut sejalan dengan kiblat tradisi batik tulis di Ciamis, yang lebih mengadopsi tradisi batik Jawa Tengah, Yogyakarta. Latar belakang sejarah kebesaran Kerajaan Galuh dan Keraton Yogja menjadi pemadu tradisi kedua daerah yang berjauhan ini. Oleh karena itu tidaklah heran jika batik tulis Ciamisan lebih berkesan menak dengan dua motif utama yakni motif rereng eneng untuk bahan dasar baju dan motif rereng seno yang biasa digunakan untuk samping atau kain.

Perkembangan selanjutnya, memasuki zaman sekarang, tradisi batik tulis dari ketiga daerah tersebut di atas (Ciamis, Garut, dan Tasikmalaya) nyaris tinggal nama. Kebesaran batik Ciamisan, batik Garutan, maupun batik Tasikan sudah tenggelam dalam kemajuan zaman, terpuruk oleh kemajuan industri tekstil yang serba cetak termasuk industri batik cetak (printing).

Dalam keterpurukan, batik Tasikan maupun batik Garutan mungkin lebih beruntung, karena masih banyak pewaris tradisi turun temurun yang bertahan. Selain itu sisa-sisa aset kejayaan tradisi di Tasikmalaya pun masih berdiri kokoh, 
seperti Gedung Mitra Batik di Jalan Mitra Batik yang kini sudah menjadi Toserba Yogja. Ada pula TK, SD dan SMK Mitra Batik maupun ruang VIP Mitra Batik di RSU Tasikmalaya. Tak hanya itu, Koperasi Mitra Batik ada sebagai bukti bahwa perajin batik di Tasikmalaya pernah berjaya dan menjadi penggerak ekonomi di kawasan tersebut.

Tidak hanya Tasikmalaya, ternyata Ciamis pun pernah mengalami masa-masa jaya tradisi batik tulis. Dengan memiliki kekhasan sendiri, batik Ciamisan memiliki pangsa pasar yang tinggi atau luas. Waktu itu batik sarian dipelopori antara lain oleh tokoh batik $\mathrm{H}$. Abdul Majid, $\mathrm{H}$. Gandaatmadja, Sasmita, Suganda, dan H. Tamim. Mereka juga waktu itu terbilang juragan batik yang sukses dalam usaha pembatikan.

Ketika ratusan perajin batik di Tasikmalaya mendirikan Koperasi Mitra Batik pada awal tahun 1939, para perajin batik di Ciamis juga tak ketinggalan dengan mendirikan Koperasi Rukun Batik yang berbadan hukum Oprichtings Acte Batik Cooperatie Rukun Batik. H. Abdul Majid, Sasmita, Suganda, dan H. Tamim, tercatat sebagai pelopor pendirian Koperasi Rukun Batik ini.

Ratusan perajin batik Ciamisan bersama Koperasi Rukun Batik ini menikmati masa jayanya di era tahun 1960-an sampai awal 1980-an. Sebanyak 1.200 perajin menekuni batik tulis motif Ciamisan. Bahkan pada era itu, mereka yang akan membeli harus rela menunggu paling cepat seminggu, barulah mendapatkan pesanannya. Para pemesan batik khas daerah Ciamis ini, tidak datang dari daerah sekitar Jawa Barat atau Jakarta, tapi dari Surabaya, Semarang, Samarinda, Banjarmasin, hingga Makassar.

Dari sekitar 1.200 perajin batik di atas, sekitar 421 perajin di antaranya menjadi anggota Koperasi Rukun Batik. Koperasi tersebut dapat memenuhi segala kebutuhan usaha mereka, mulai dari bahan baku sampai pemasaran produk.
Pemasaran batik hasil perajin di Ciamis dan Tasikmalaya tidak hanya dilakukan ke kota-kota di tanah air saja, juga sampai ke negeri tetangga, Semenanjung Malaysia. Batik Ciamisan pun mampu bersaing di antara dominasi tradisi batik Solo, Yogja maupun batik Pekalongan. Bahkan bersama Koperasi Mitra Batik, Koperasi Rukun Batik menjadi penggagas berdirinya Gabungan Koperasi Batik Indonesia (GKBI). Jadi, yang tergabung dalam GKBI dari Jawa Barat adalah Koperasi Mitra Batik (Tasikmalaya), Koperasi Rukun Batik (Ciamis), Koperasi Warga Batik (Garut), Batik Trusmi (Cirebon), dan Perubudi (Indramayu).

Waktu terus berjalan seiring dengan usaha pakaian jadi di berbagai kota semakin berkembang. Hal itu berdampak pada usaha batik tradisional. Khususnya di Ciamis, memasuki akhir tahun 1970-an, pemesanan batik mulai mengalami penurunan. Akhirnya pada tahun 1980-an, para perajin batik di Ciamis beralih dari batik tulis ke cap. Hal itu disebabkan masyarakat lebih menyukai batik cetak yang harganya jauh lebih murah. CV Bintang Pusaka, milik salah seorang tokoh batik di Ciamispun mengubah haluan dan membuat batik cetak. Batik tulis yang pembuatannya memakan waktu lama dan berharga mahal ditinggalkan.

Namun, usaha batik cap pun terus berkurang. Devaluasi yang terjadi pada tahun 1980-an, dari Rp 324,- menjadi Rp 750, berdampak hebat pada usaha batik di Ciamis. Jumlah perajin batik terus menyusut hingga menjadi 434 orang.

Padatahun 1980-an pula, para perajin batik Ciamisan yang bergabung dalam Koperasi Rukun Batik berhasil membeli sejumlah aset, bahkan sampai mendirikan pabrik kain bahan baku batik (cambrice) yang berdiri di Jalan Sudirman No. 249 Ciamis. Pabrik ini sekaligus dijadikan sebagai markas Koperasi Rukun Batik hingga sekarang. Aset-aset lainnya, di antaranya berupa sekolah di Cikoneng dan klinik berobat di Imbanagara. 
Namun sejak berkembangnya batik buatan pabrik (batik printing) dan dominasi warga keturunan dalam tata niaga batik pada tahun 1980-an, pertumbuhan batik Ciamisan mulai menyurut. Terlebih setelah terjadi letusan Gunung Galunggung pada tahun 1982 yang terus menerus menyemburkan debu vulkanik. Debu tersebut menyebabkan matahari nyaris tak terlihat selama setahun.Akibatnya, para perajin tak bisa menjemur batik hasil karya mereka karena tidak ada cahaya matahari.

Selanjutnya pada tahun 1986 terjadi lagi devaluasi, dari $\mathrm{Rp} 750$,- menjadi $\mathrm{Rp}$ 1.750,-. Anggota koperasi semakin banyak yang berhenti (di atas $75 \%$ ). Kain mori buatan Jepang, sebagai bahan batik pun semakin sulit dibeli. Situasi dan kondisi yang serba susah pada masa itu terus berlanjut. Hal itu membuat satu per satu perajin batik Ciamisan menghentikan usaha mereka.

Puncaknya, manakala pada tahun 1997 terjadi krisis moneter, 434 perajin batik Ciamisan resmi gulung tikar. Koperasi Rukun Batik pun goyah. Sementara pabrik Camrice sendiri sudah lama tak beroperasi. Pukulan hebat yang dialami para perajin batik adalah harga obat-obatan yang diimpor dari luar negeri menjadi berlipat-lipat seiring anjloknya mata uang rupiah terhadap dollar AS.

Dalam mempertahankan keberadaannya, Koperasi Rukun Batik berupaya melakukan peragaman usaha. Sejumlah usaha yang hampir tak ada kaitannya dengan batik dilakukan, seperti beternak sapi potong, menyewakan gudang pabrik untuk jadi gudang cengkeh. Kemudian pada tahun 2005, halaman pabrik Camrice Rukun Batik diubah jadi rumah petak untuk dikontrakkan. Rumah kontrakan di kawasan elit tersebut ternyata banyak peminatnya. Pengontraknya datang dari berbagai profesi. Tak hanya itu, halaman luas di depan deretan rumah petak Rukun Batik tersebut pernah ditanami jagung dan cabe. Akan halnya Poliklinik Berobat di Imbanagara sekarang sudah menjadi komplek pertokoan yang mentereng, sedangkan bekas gedung SMP Rukun Batik di Cikoneng di sisi jalan raya Ciamis-Tasikmalaya pernah menjadi sarang kapinis.

Memasuki tahun 2000, di antara 434 perajin batik Ciamisan yang masih eksis hanya tinggal seorang, yakni H. Otong Kartiman (69 thn), warga Cihawangan, Desa Imbanagara, Kabupaten Ciamis. Ayah dari empat anak ini dapat dikatakan sebagai penyelamat batik Ciamisan. Seandainya dulu ia mengikuti jejak para perajin lainnya, tentunya batik Ciamisan tinggal namanya saja sekarang. Ia tetap bertahan dalam usahanya, hingga sekarang memiliki pabrik batik dengan bendera Bintang Pusaka di rumahnya, di Dusun Ciwahangan Imbanagara.

Otong Kartiman mewarisi tradisi membatik ini dari orangtuanya, H. Abdul Majid yang merupakan salah seorang pelopor batik Ciamisan pada tahun 1956. Saat itu Otong Kartiman masih sekolah di sebuah SMA di Yogyakarta, tapi oleh kedua orangtuanya, yakni $\mathrm{H}$. Abdul Majid dan Ny. Hj. Unah Siti Chodijah, ia disuruh pulang untuk melanjutkan usaha batik keluarga tersebut.

Otong K. mengaku, ia bertahan dalam usaha batik Ciamisan karena rasa cintanya akan seni batik Ciamisan. Sejak usia 20 tahunan, ia sudah terjun dalam usaha batik. Bahkan di lingkungan keluarga besarnya, ia termasuk pembatik yang bagus. Pada tahun 60 -an, keluarganya pernah memiliki pegawai sekitar 200 orang. Akibat situasi ekonomi yang tidak stabil, jumlah pegawai terus berkurang hingga kemudian tinggal 30 orang. Tahun 1980-an usaha batiknya beralih dari tulis ke cap. Hal itu ia lakukan karena situasi ekonomi sangat sulit untuk tetap bertahan di batik tulis. Walaupun fokus ke cap, Otong tetap membuka tangan jika ada yang memesan batik tradisional tulis Ciamisan, yang pada kenyataannya sangat jarang ada. Selain membutuhkan waktu yang lama dalam pembuatannya, juga harga batik tulis tentu lebih mahal. 
H. Oma Sasmita SH, Msi, ketika menjabat sebagai Bupati Ciamis (1999. 2004) pernah mewajibkan para pejabat eselon lingkup Pemkab Ciamis setiap hari Jumat memakai pakaian batik Ciamisan. Kewajiban menggunakan batik Ciamisan tersebut tak hanya berlaku di markas besar Pemkab Ciamis saja, tetapi juga sampai ke kecamatan dan desa. Pada waktu itu, H. Otong Kartiman pun kebanjiran pesanan batik Ciamisan.

Sekarang $H$. Otong Kartiman kembali menjalani usahanya dengan fokus utama pada batik cap danprinting untuk memenuhi permintaan pasar Tanah Abang (Jakarta), Bandung, Surabaya, dan Makassar. H. Otong dengan Bintang Pusaka-nya kini memproduksi batik printing sesuai dengan keinginan pasar, termasuk memenuhi permintaan batik untuk seragam sekolah. Otong mengaku saat ini setiap hari memproduksi 150 kodi kain batik (satu kodi $=20$ lembar). Harga setiap kodinya dari yangpaling murah $\mathrm{Rp}$ 250.000,00 hingga Rp 4-000.000,00.

$\mathrm{H}$. Otong juga telah memodifikasi mesinnya dengan yang terbaru, dan para pegawai yang dulu diliburkan sekarang bekerja lagi. Jumlah pekerjanya sekarang kurang lebih ada 80 orang. Mereka menjalankan proses produksi yang sebagian besar sudah dilakukan dengan mesin. Bahkan, ia sedang berusaha untuk memperluas pabriknya ke bagian belakang. Kini semua produknya adalah batik cetak.

Kiatnya untuk mempertahankan pemasaran, H. Otong setiap dua minggu sekali datang ke pasar, baik ke Pasar Senen, Tanah Abang Jakarta, ke Surabaya hingga ke Makassar untuk menanyakan kecenderungan selera konsumen batik. Jadi batik apa yang digemari pasar, maka batik yang dibuat pun mengikuti pasar. Hal itu bukan berarti batik Ciamisan mereka tinggal, tetapi mereka pun berusaha membaca keinginan konsumen. Jadi, batik secara umum pun mereka produksi, dalam artian produknya tidak hanya batik Ciamisan, tetapi juga batik Pekalongan,
Solo, Garut, atau Cirebon. Motifnya pun bisa dibuat sesuai pesanan.

Usaha $\mathrm{H}$. Otong ini tidak langsung membesar. Pada awalnya, ia yang harus menawarkan dagangannya ke toko-toko di berbagai kota di atas, sekarang hal itu tak perlu lagi dilakukan. Para pedagang telah mengenal pengusaha batik dan produknya. Nama perusahaannya, Bintang Pusaka, ia pilih dengan alasan religius. Bintang mengingatkannya untuk menjadi umat yang taat pada lima Rukun Islam.

Dengan batik inilah Otong membesarkan dan menyekolahkan empat putri dan seorang putranya. Kini ia juga mempunyai 17 cucu. Dari kelima anaknya, putranya, H. Pepep Ukimulyana (49 thn), mengikuti jejak ayahnya dan terjun ke usaha batik. Dialah yang sekarang memimpin bagian produksi. Pria kelahiran Ciamis ini juga aktif di Koperasi Rukun Batik. Kegiatannya ini didukung kemampuan administrasi yang diperoleh dari kursus administrasi selama setahun di Ciamis.

Koperasi itu mewadahi 421 pengusaha batik di Kabupaten Ciamis. Namun sayang, banyak pengusaha batik yang gulung tikar ketika terjadi krisis moneter tahun 1997. Kini, menurut Otong, Koperasi Rukun Batik bergerak di bidang usaha sampingan seperti perkebunan.

Otong menyebut caranya mengelola usaha sebagai manajemen sarungan. Sehari-hari ia tidak berlaku formal dengan karyawannya. Ini yang dinamakannya sebagai gaya sarungan. Sedikitnya sebulan sekali karyawan berkumpul dengan pimpinan untuk evaluasi.

Ia pun menyebutkan kiatnya mempertahankan perusahaan, yaitupenting menjaga kualitas dan kuantitas produk, kualitas bahan, serta harus ada efisiensi pada produksi dan jumlah karyawan. Sementara itu upaya mengajukanhak cipta untuk batik khas Ciamisan ini pun dilakukan H. Otong, agar tidak diambil alih oleh orang lain. Usahanya kini diteruskan oleh anak keduanya, H. Pepep Ukimulyana. 
Penghargaan yang pernah diraih Otong Kartiman di antaranya Asian Executive Man Golden Award tanggal 10 Maret 2005 di Hotel Kartika Chandra, Jakarta.

\section{Corak Batik Ciamisan}

Menyikapi ketetapan UNESCO bahwa Batik sebagai The World Cultural Heritage of Humanity from Indonesia, Koperasi Rukun Batik pun bekerjasama dengan Yayasan Batik Jawa Barat (YBJB) mendirikan sanggar pelatihan batik dengan bangunan saung khas Sunda di pekarangan pabrik di Komplek Koperasi Rukun Batik Ciamis. Sebagai penanggungjawab Sanggar adalah M. Toha (40 thn), yang sekaligus juga penanggungjawab Galeri Batik Koperasi Rukun Batik Ciamis

M. Toha mengatakan bahwa, membangkitkan kebesaran batik tulis Ciamisan yang pernah berjaya di era tahun 1960-1980-an tersebut bagaikan menggali kembali serpihan-serpihan sejarah batik Ciamisan yang pernah terkubur lama. Seperti dengan menginventarisir kembali motif-motif batik Ciamisan tempo dulu. Dari buku-buku katalog batik dan dari koleksi para pengusaha batik Ciamisan maupun dari masyarakat sudah terdata sekitar 25 jenis motif batik tulis Ciamisan yang pernah dibuat para pengrajin batik Ciamis tempo dulu, yang bermuara pada filosofi kesederhanaan. Kesahajaan merupakan ciri khas batik Ciamisan.

Toha pun menambahkan, ciri khas motif batik tulis tempo dulu adalah penggunaan warna yang sederhana, yaitu warna hitam dan putih yang begitu menonjol dengan paduan hitam dan coklat (saga). Itulah sebabnya batik Ciamisan sering disebut batik sarian, karena pilihan warna yang sederhana tersebut. Kemudian dari 25 motif yang sudah terinventarisir, ternyata motif rereng seno merupakan motif batik Ciamisan yang paling diminati saat batik Ciamisan berjaya tahun 19601980-an lalu. Ciamisan memiliki dua motif rereng, yakni rereng eneng dan rereng seno. Motif rereng eneng kini diaplikasi- kan untuk baju, sedangkan rereng seno untuk kain bawahan.

Tiga warna yang dominan dalam batik Ciamisan, yaitu putih, hitam, dan coklat (saga) memberikan arti yang sederhana. Hal itu menunjukkan bahwa warga Ciamis dalam keseharian sederhana dan ramah, tidak berbelit-belit. Dengan kesederhanaan, orang Ciamis tetap ingin mempesona. Putih menggambarkan hati bersih, sedangkan hitam dan coklat adalah ketegasan. Pemilihan warna putih dan hitam ini juga banyak mengiblat ke batik Yogya.

Ragam hias batik Ciamisan bernuansa naturalistik, yang banyak menggambarkan flora dan fauna serta lingkungan alam sekitar. Tanaman daun rente dan daun kelapa, adalah dua jenis tanaman yang dijadikan gambar ciri khas Ciamisan. Tanaman rente yang biasa tumbuh di kolam-kolam penduduk Ciamis dan dijadikan pakan ikan, diangkat pada kain mori dan dituangkan jadi gambar untuk batiknya. Demikian pula keakraban perajin batik dengan pohon kelapa yang banyak tumbuh di daerah itu, jadi ilham untuk motif Ciamisan. Motif Ciamisan tampil sebagai kain yang kalem. Mungkin ini sesuai dengan jiwa masyarakat Ciamis yang tenang dan tidak bergejolak.

Kesederhanaan corak batik Ciamisan tak lepas dari keberadaannya yang banyak dipengaruhi daerah lain, seperti ragam hias pesisiran dari Indramayu dan Cirebon. Selain itu, pengaruh batik nonpesisiran seperti Solo dan Yogyakarta tak kalah dominan. Pengaruh dari wilayah pesisir dan nonpesisir yang berpadu dengan nilai-nilai budaya Sunda dan kehidupan sosial sehari-hari masyarakat Ciamis melahirkan ragam motif batik Ciamisan yang sesuai dengan gaya dan selera masyarakat setempat, bersahaja tetapi elegan.

Jadi dapat dikatakan, corak batik Ciamisan tidak memiliki makna filosofi perlambang, nilai sakral, atau menunjukkan status sosial tertentu. Namun penciptaan motif atau ragam hias batiknya lebih 
ditekankan pada ungkapan kesederhanaan untuk memenuhi kebutuhan sandang, sinjang/samping 'kain' bagi masyarakat. Filosofi kesederhanaannya itu tertuang dalam bentuk-bentuk yang terinspirasi dari alam sekitar dan kejadian sehari-hari.

Motif alam sekitar yang banyak dijumpai dalam batik Ciamisan adalah rereng atau lereng. Motif yang menggambarkan tebing miring ini dipengaruhi motif parang pada batik Jawa Tengah. Motif lain adalah kumeli, berupa empat bentuk yang mengelilingi pusat dan cupat manggu, motif geometris bergambar buah manggis.

Berikut ini beberapa motif batik Ciamisan dari 25 motif yang telah terinventarisir pengurus Sanggar dan Galeri Batik Koperasi Rukun Batik Ciamis: parang sontak, rereng seno, rereng sintung ageung, kopi pecah, lepean, rereng parang rusak, rereng adu manis, kumeli, rereng parang ali, rereng useup, rereng jenggot, rereng peuteuy papangkuh, rereng suliga, dan rereng eneng.

Berbagai motif batik Ciamisan.

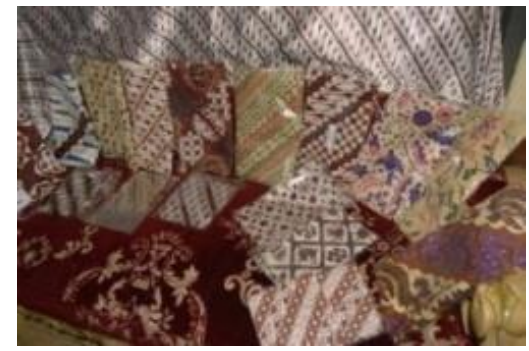

Sumber: http://m.tribunjabar.co.id/

Berbagai motif batik tulis Ciamisan.

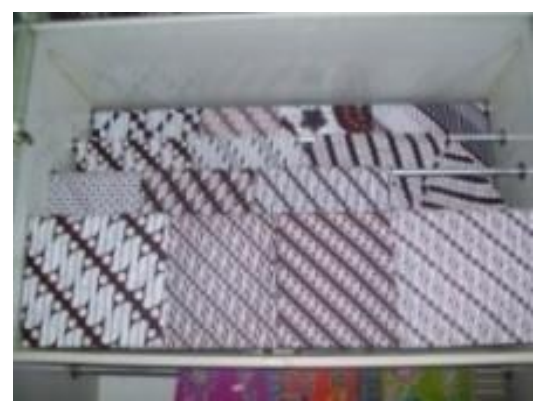

Sumber: Penelitian Tahun 2011.

Motif Suliga (Ageung)Motif Suliga Titik (Alit)Motif Kawung Picis (Kumelian)

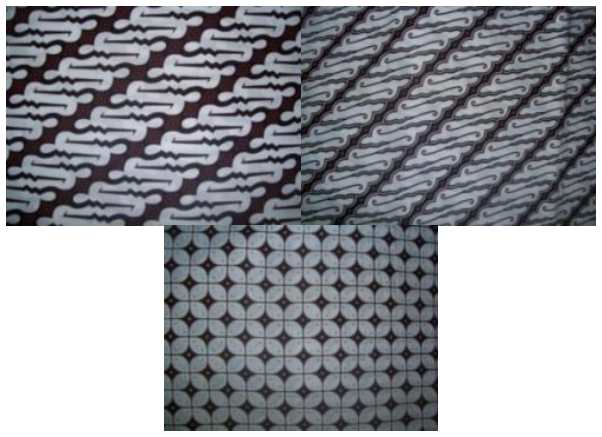

Sumber: Penelitian Tahun 2011. Motif Lereng Sulika

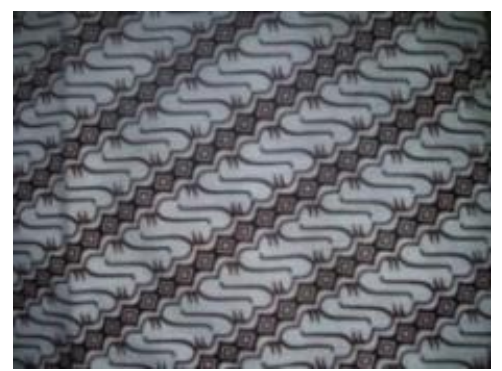

Sumber: Penelitian Tahun 2011. AlitMotif Kopi Pecah

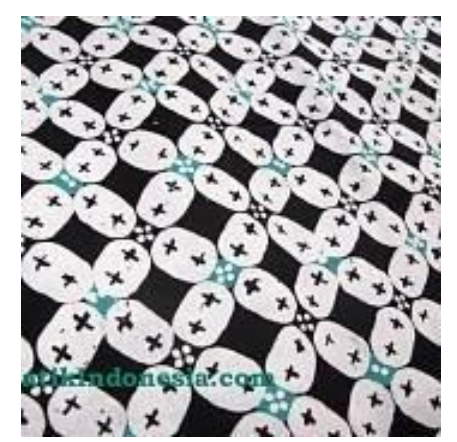

Sumber: batikindonesia.com

\section{Kebangkitan Batik Ciamisan}

Keputusan UNESCO yang telah menetapkan batik sebagai hak warisan budaya Indonesia merupakan penyemangat luar biasa bagi pengurus Koperasi Rukun Batik Ciamis untuk membangunkan kembali tradisi batik Ciamisan yang sempat terlelap 30-an tahun, salah satunya adalah dengan mendirikan sanggar pelatihan batik. Apalagi keputusan UNESCO kemudian diikuti semangat kebanggaan memakai batik. Kantor-kantor dinas, swasta, BUMN/BUMD karyawannya ramai-ramai memakai baju batik pada hari tertentu yang 
sudah dijadwalkan. Bahkan, Bupati Ciamis H. Engkon Komara mengimbau para PNS di berbagai dinas/jawatan lingkup Pemkab. Ciamis untuk menggunakan baju batik Ciamisan setiap hari Kamis dan Jumat.

Sanggar pelatihan batik yang bangunannya berupa saung khas Sunda di pekarangan pabrik di Komplek Koperasi Rukun Batik Ciamis dan berada di antara kesejukan hamparan pohon jati dan pohon pepaya di pekarangan yang luas, telah memulai melakukan aktivitasnya. Pada awalnya mereka melatih warga dan anak-anak sekolah (generasi muda) Ciamis yang ingin belajar membatik dengan tujuan agar batik Ciamisan bisa lebih dikenal oleh warga Ciamis maupun luar kota. Kemudian tanpa meninggalkan misi tersebut, mereka pun kini memproduksi batik tulis Ciamisan kembali, seperti para pengrajin batik lainnya di Ciamis, dengan mempekerjakan sedikitnya dua puluh orang pekerja. Kain batiknya mereka pasarkan dengan harga yang terjangkau oleh masyarakat.

Keberadaan sanggar batik ini menurut Toha, telah membuat sejumlah pegiat batik Ciamisan tempo dulu turun gunung. Seperti tukang tulis batik (penyerat), tukang cap, mandor godog, dan juru warna. H. Oong (64 thn), sebagai ahli pewarnapun turun gunung untuk berbagi ilmu.

Para pebatik dulu yang kembali berkiprah di perbatikan, menghidupkan kembali motif-motif lama batik Ciamisan. Pada tahun 2010 baru tiga motif lama yang kembali diperkenalkan, yaitu motif parang sontak, galuh pakuan, dan suliga adumanis.

Motif parang sontak bergambar golok biasa digunakan masyarakat umum maupun hulubalang saat Kerajaan Galuh masih berkuasa. Kemudian motif galuh pakuan, merupakan apresiasi para disainer batik Ciamisan tempo dulu terhadap benda pusaka peninggalan raja-raja Galuh, yakni berupa keris. Siluet gagang keris pusaka, menjadi bagian keindahan lukisan batik motif galuh pakuan ini. Adapun motif suliga adumanis merupakan perpaduan antara motif suliga (senjata keris) dan adumanis (galendo).

Berbeda dengan motif lama yang sangat sederhana dalam pewarnaannya, yaitu hanya menggunakan warna coklat (soga) dan putih (batik sarian), motif lama batik Ciamisan dengan versi baru sekarang ini lebih meriah dalam pilihan warnanya. Hal itu disesuaikan dengan selera saat ini. Selain warna-warna lama yaitu putih, hitam dan cokelat kekuningan, batik Ciamisan kini juga menggunakan warna seperti hijau dan merah sebagai aksen.

Selain menghidupkan kembali tiga motif lama tersebut di atas, Sanggar Batik Rukun Batik pun telah meluncurkan dua motif baru hasil inovasi tim kreatif, tim Sanggar Batik Rukun Batik Ciamis dan Yayasan Batik Jawa Barat dengan slogan budaya Ciamis dan tempat wisata. Kedua motif baru batik Ciamisan era 2010 tersebut diberi nama motif Ciung Wanara dan motif Batu Hiu. Sesuai dengan namanya batik Ciamisan motif Batu Hiu ini menggambarkan keindahan basisir laut kidul 'pantai selatan' Batu Hiu Parigi. Ujung-ujung lidah ombak terpatri jelas di motif Batu Hiu ini. Adapun motif Ciung Wanara merupakan apresiasi dari legenda kebesaran Ciung Wanara (Manarah), Raja Galuh Karangkamulyaan. Berikut ini kisah tentang Ciung Wanara.

Ciung Wanara (Manarah) adalah keturunan raja. Ketika bayi, ia dihanyutkan ke Sungai Citanduy namun diselamatkan seorang petapa. Alkisah, setelah dewasa, Ciung Wanara pun kembali ke pusat Kerajaan Galuh di Karangkamulyaan sambil membawa ayam aduan. Manarah kembali ke tampuk kekuasaan Kerajaan Galuh setelah ayamnya menang di medan aduan. Itulah sebabnya motif batik Ciamisan Ciung Wanara ini digambarkan dengan sayap dan ekor ayam jago, keranjang tempat mengangkut ayam, dan kurungan ayam aduan. Motif Ciung Wanara ini termasuk motif favorit konsumen, seperti halnya motif Galuh Pakuan. 


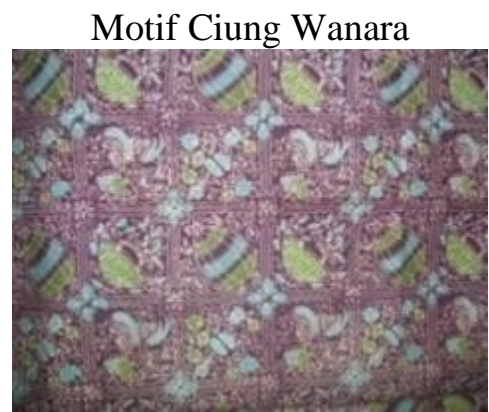

Sumber: Penelitian Tahun 2011.

Dengan adanya sanggar, kini sudah terbentuk kelompok batik di Dusun Cibeunying, Desa Cisadap yang mulai memproduksi batik tulis Ciamisan. Toha menargetkan kelompok serupa juga akan muncul di Desa Imbanagara dan Desa Cikoneng yang dulu merupakan sentra kerajinan batik tulis Ciamisan.

\section{Proses Pembuatan Batik Ciamisan}

Sebelum menginjak pada proses pembuatan batik, perlu diketahui terlebih dahulu perbedaan antara batik tulis, batik cap, dan batik print. Batik tulis dikerjakan dengan menggunakan canting, yaitu alat yang terbuat dari tembaga yang dibentuk sedemikian rupa sehingga dapat menampung cairan malam (lilin batik) dan ujungnya berupa saluran/pipa kecil untuk keluarnya malam. Canting digunakan dalam membentuk gambar awal pada permukaan kain.

Bentuk gambar atau disain pada batik tulis tidak ada pengulangan yang jelas, sehingga gambar nampak bisa lebih luwes dengan ukuran garis motif yang relatif bisa lebih kecil dibandingkan dengan batik cap. Kemudian gambar batik tulis bisa dilihat pada kedua sisi kain nampak lebih rata (tembus bolak-balik), khusus bagi batik tulis yang halus. Warna dasar kain biasanya lebih muda dibandingkan dengan warna pada goresan motif (batik tulis putihan/tembokan). Setiap potongan gambar (ragam hias) yang diulang pada lembar kain biasanya tidak akan pernah sama bentuk dan ukurannya. Lain dengan batik cap, yang kemungkinannya bisa sama persis antara gambar yang satu dengan gambar lainnya.
Waktu yang dibutuhkan untuk pembuatan batik tulis relatif lebih lama (2 atau 3 kali lebih lama) dibandingkan dengan pembuatan batik cap. Pengerjaan batik tulis yang halus bisa memakan waktu 3 hingga 6 bulan lamanya. Alat kerja berupa canting harganya relatif lebih murah, berkisar Rp. 10.000,- hingga Rp. 20.000,/buah. Harga jual batik tulis relatif lebih mahal, disebabkan dari sisi kualitas biasanya lebih bagus, mewah, dan unik.

Adapun batik cap, pengerjaannya menggunakan cap, yaitu alat yang terbuat dari tembaga yang dibentuk sesuai dengan gambar atau motif yang dikehendaki. Cap, yang merupakan alat yang ditemukan kemudian, pada dasarnya meniru canting. Memang tujuan pembuatan cap diarahkan untuk meniru canting setepat mungkin dan dengan tingkat efesiensi setinggi mungkin. Peniruan ini didorong oleh kebutuhan akan ragam hias yang penuh dengan rincian berupa garis atau titik.

Untuk pembuatan satu gagang cap batik dengan dimensi panjang dan lebar : $20 \mathrm{~cm} \mathrm{X} 20 \mathrm{~cm}$ dibutuhkan waktu rata-rata 2 minggu. Bentuk gambar/desain pada batik cap selalu ada pengulangan yang jelas, sehingga gambar nampak berulang dengan bentuk yang sama serta ukuran garis motif relatif lebih besar dibandingkan dengan batik tulis. Gambar batik cap biasanya tidak tembus pada kedua sisi kain. Warna dasar kain biasanya lebih tua dibandingkan dengan warna pada goresan motifnya. Hal ini disebabkan batik cap tidak melakukan penutupan pada bagian dasar motif yang lebih rumit seperti halnya yang biasa dilakukan pada proses batik tulis. Korelasinya yaitu dengan mengejar harga jual yang lebih murah dan waktu produksi yang lebih cepat. Waktu yang dibutuhkan untuk sehelai kain batik cap berkisar 1 hingga 3 minggu. Untuk membuat batik cap yang beragam motif, maka diperlukan banyak cap. Sementara harga cap batik relatif lebih mahal dari canting. Untuk harga cap batik pada kondisi sekarang dengan ukuran $20 \mathrm{~cm} \mathrm{X}$ $20 \mathrm{~cm}$ berkisar Rp. 350.000,- hingga Rp. 
700.000,-/motif. Sehingga dari sisi modal awal batik cap relatif lebih mahal. Jangka waktu pemakaian cap batik dalam kondisi yang baik bisa mencapai 5 tahun hingga 10 tahun, dengan catatan tidak rusak. Pengulangan cap batik tembaga untuk pemakainnya hampir tidak terbatas. Harga jual batik cap relatif lebih murah dibandingkan dengan batik tulis, disebabkan biasanya jumlahnya banyak dan memiliki kesamaan satu dan lainnya, tidak unik, tidak istimewa, dan kurang eksklusif.

Batik printsendiri merupakan salah satu jenis batik yang baru muncul. Tidak diketahui pasti kapan mulai dikenal, tetapi kini menjadi produksi batik dengan jumlah paling banyak jika dibanding batik cap apalagi batik tulis.

Teknik pembuatan batik print relatif sama dengan produksi sablon, yaitu menggunakan klise (kassa) untuk mencetak motif batik di atas kain. Proses pewarnaannya sama dengan proses pembuatan tekstil biasa, yaitu dengan menggunakan pasta yang telah dicampur pewarna sesuai keinginan, kemudian diprint-kan sesuai motif yang telah dibuat. Jenis batik ini dapat diproduksi dalam jumlah besar karena tidak melalui proses penempelan lilin dan pencelupan seperti batik pada umumnya, hanya saja motif yang dibuat adalah motif batik. oleh karena itu batik print merupakan salah satu jenis batik yang fenomenal, kemunculannya dipertanyakan oleh beberapa seniman dan pengrajin batik karena dianggap merusak tatanan dalam seni batik, sehingga mereka lebih suka menyebutnya kain bermotif batik.

\section{Proses Pembuatan Batik Tulis Ciamisan}

Peralatan yang diperlukan dalam pembuatan batik tulis Ciamisan adalah canting sebagai alat pembentuk motif, kuas, gawangan (tempat untuk menyampirkan kain), bandul, wajan, taplak, saringan malam, dingklik, dan kompor kecil untuk memanaskan.
Seperti yang telah dijelaskan sebelumnya, canting adalahalat yang terbuat dari tembaga yang dibentuk sedemikian rupa, yang digunakan untuk membentuk gambar awal pada permukaan kain. Selain canting untuk membuat gambar awal dapat menggunakan kuas juga. Struktur canting terdiri atas tiga bagian, yaitu carat/cucuk, penampung malam, dan pegangan (lihat gambar).

Bagian carat/cucuk adalah bagian yang menyalurkan malam dari bagian penampungan malam. Bagian ini berupa pipa tembaga kecil yang bagian ujungnya disebut mata canting. Ukuran mata canting ada yang kecil, sedang, dan besar, yang digunakan sebagai dasar untuk menentukan seri canting. Bagian penampung malam bentuknya berongga dan terbuka bagian atasnya untuk memasukkan cairan malam. Cairan malam pada bagian penampung tersebut jika dimiringkan ke arah carat akan mengalir ke dalam carat dan keluar melalui mata canting. Bagian pegangan canting berbentuk memanjang dengan bagian ujungnya difungsikan sebagain dudukan penampung dan pengikat carat. Bagian pegangan ini terbuat dari bambu yang bersifat meredam panas. Bagian carat dan penampung terbuat dari tembaga, karena tembaga adalah logam yang baik sebagai konduktor (penghantar panas). Ketebalan tembaga dipilih yang paling tipis untuk memudahkan dilekukkan dan dibuat carat.

Gawangan adalah tempat untuk menyampirkan kain yang akan dibatik, terbuat dari bahan bambu (lihat gambar) atau kayu. Gawangan harus dibuat sedemikian rupa, sehingga mudah dipindah - pindah, tetapi harus kuat dan ringan.

Bandul dibuat dari timah, atau kayu, atau batu yang di kantongi. Fungsi pokok bandul ialah untuk menahan mori yang baru dibatik agar tidak mudah tergeser ditiup angin, atau tarikan si pembatik secara tidak sengaja. Jadi tanpa bandul pekerjaan membatik dapat saja dilaksanakan.Kemudian taplak ialah kain 
untuk menutup paha si pembatik agar tidak terkena tetesan malam panas sewaktu canting ditiup atau waktu membatik. Taplak biasanya dibuat dari kain bekas.Adapun dingklik atau lincak pada prinsipnya sama, tempat duduk si pembatik. Tetapi pembatik dapat pula duduk diatas tikar.

Wajan sebagai wadah, tempat mencairkan malam atau lilin batik di atas kompor. Wajan terbuat dari logam baja atau tanah liat dan sebaiknya bertelinga atau bertangkai, agar mudah diangkat dan diturunkan dari perapian tanpa mempergunakan alat lain. Pada telinga wajan dimasukkan sebatang kayu yang digunakan untuk mengangkat dan menyimpan wajan di atas kompor (lihat gambar).

\section{Gawangan yang terbuat dari bambu}

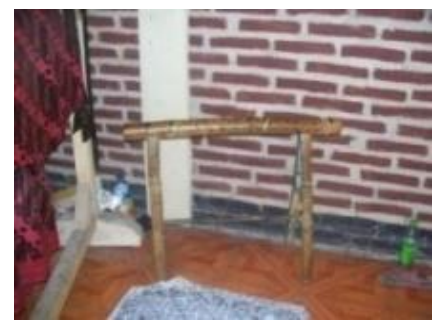

Wajan, tempat mencairkan malam

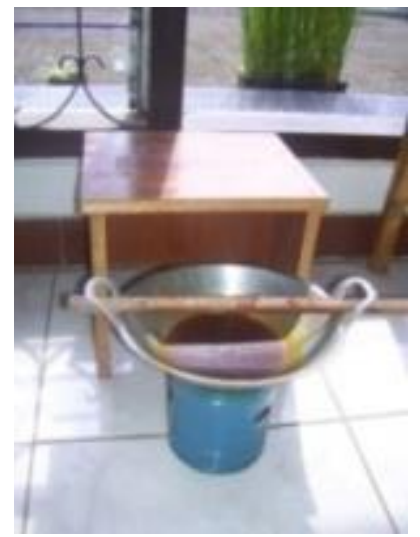

Canting, alat pembentuk motif batik.

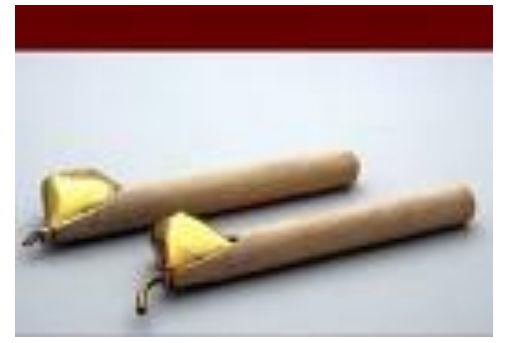

Sumber: Penelitian BPSNT2011. Sumber:

http://finunu.wordpress.com/tag/pewarnabatik/

Saringan malam ialah alat untuk menyaring malam panas yang banyak kotorannya. Jika malam disaring, maka kotoran dapat dibuang, sehingga tidak mengganggu jalannya pada carat atau cucuk canting sewaktu dipergunakan untuk membatik.

Kompor minyak tanah dipergunakan untuk memanasi malam agar cair. Kompor yang digunakan biasanya ukurannya kecil, berdiameter $13 \mathrm{~cm} \mathrm{-}$ sesuai dengan besaran wajan yang digunakan. Pembatik tradisional dulu menggunakan anglo dengan arang sebagai bahan bakar. Kelemahan anglo adalah asap yang ditimbulkannya berbeda dengan kompor yang tidak seberapa menimbulkan asap. Pemanasan malam tidak membutuhkan api yang cukup besar, seperti halnya memasak di dapur.

Adapun bahan-bahan yang digunakan untuk membatik adalah mori atau kain putih, malam (lilin batik) yang dicairkan, zat pewarna, dan larutan bahan kimia. Umumnya, serat yang biasa dipakai untuk batik adalah katun, sutera, poliester, dan rayon. Serat-serat tersebut dapat dipakai untuk membatik karena berasal dari alam dan mampu mengikat warna dalam temperatur rendah. Kain katun yang dipakai untuk batik umumnya belum dicelup, sehingga masih berwarna putih. Ada dua macam kain putih. Kain putih yang telah diputihkan dengan olahan dari pabrik disebut kain mori, muslim atau cambric; kain putih yang belum diolah disebut blacu. 
Kata mori berasal dari "bombyx mori", yaitu sejenis ulat sutra yang menghasilkan sutera putih dan halus. Kain mori, dalam kualitas tertentu akan menghasilkan kilauan cahaya seperti kain sutera jenis bombyx mori. Adapun kata muslim berasal dari "mousuline", yaitu nama sejenis kain cita. Adapun kata cambric berasal dari kata "fine linen" yang putih.

Jenis malam yang digunakan untuk batik tulis dengan batik cap berbeda. Perbedaan jenis malam tersebut bergantung pada perbedaan elemenelemennya, sehingga mempengaruhi perbedaan keliatan malamnya. Elemenelemen untuk membuat malam antara lain damar, gondorukem, malam tawon, malam mikro, parafin, kendal, minyak kelapa, dan malam bekas.

Malam yang siap dicairkan.

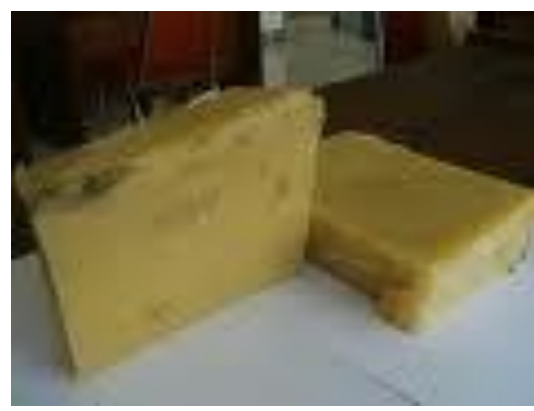

Kain mori

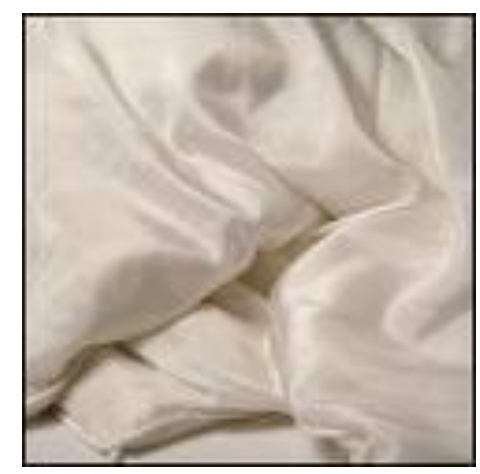

Sumber:

http://finunu.wordpress.com/tag/pewarnabatik/

Sebelum digunakan, lilin malam harus dicairkan terlebih dahulu dengan cara dipanaskan di atas kompor atau pemanas lain. Lilin malam dalam proses pembuatan batik tulis berfungsi untuk menahan warna agar tidak masuk ke dalam serat kain dibagian yang tidak dikehendaki. Adapun bagian yang akan diwarnai dibiarkan tidak ditutupi lilin

Parafin dipakai sebagai elemen malam batik karena mempunyai daya tolak yang tinggi terhadap cairan, mudah cair, cepat membeku, daya lekat kecil dan mudah lepas, titik cairnya rendah antara $60^{\circ}-65^{\circ} \mathrm{C}$, cukup tahan terhadap larutan alkali. Kemudian warna malam mikro adalah putih kekuningan dan sangat liat. Titik lelehnya $70^{\circ} \mathrm{C}$, lama menjadi cairnya, mudah lepas dalam rendaman air, sukar menembus kain, dan tahan terhadap larutan alkali. Adapun kendal atau gajih binatang mempunyai sifat mudah mencair, titik lelehnya rendah, yaitu $45^{\circ}-50^{\circ} \mathrm{C}$, dan dipakai sebagai elemen malam batik dalam jumlah relatif kecil.

Zat pewarna yang dipakai untuk membatik adalah indigosol, naftol. Zat-zat pewarna tersebut dapat dipakai untuk mencelup dan mencolet.

Berikut ini tahapan-tahapan dalam proses pembuatan batik tulis. Sebagai langkah pertama adalah membuat disain batik salah satu dari corak batik Ciamisan. Membuat disain atau motif ini dapat menggunakan pensil, kemudian melukisnya dengan malam (lilin batik), dengan menggunakan canting.

Melukis dengan canting bermalam pada kain mori.

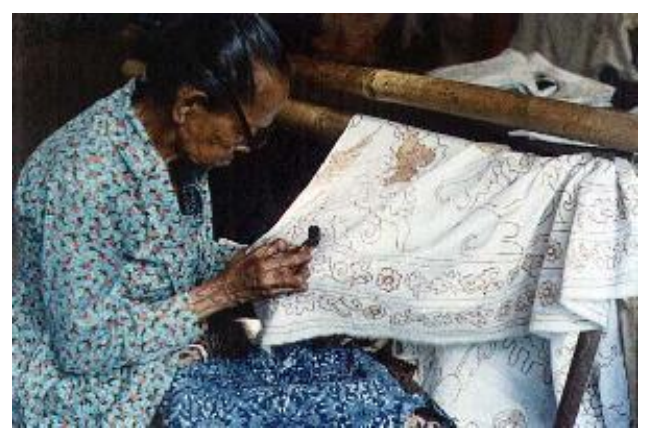

Sumber:

Tahap selanjutnya menutupi bagianbagian yang akan tetap berwarna putih (tidak berwarna) dengan malam,sehingga 
cairan lilin meresap ke dalam serat kain.Canting digunakan untuk motif bagian halus dan kuas untuk motif berukuran besar. Tujuannya adalah agar saat pencelupan bahan ke dalam larutan pewarna, bagian yang diberi lapisan lilin tidak terkena.

Berikutnya, proses pewarnaan pertama pada bagian yang tidak tertutup oleh lilin dengan mencelupkan kain tersebut pada warna tertentu.Biasanya dimulai dari warna-warna muda. Setelah dicelupkan, kain tersebut di jemur dan dikeringkan. Setelah kering, kembali melakukan proses pembatikan yaitu melukis dengan lilin malam menggunakan canting untuk menutup bagian yang akan tetap dipertahankan pada pewarnaan yang pertama. Kemudian, dilanjutkan dengan proses pencelupan warna yang kedua. Pencelupan dilakukan untuk motif lain dengan warna lebih tua atau gelap.

Proses selanjutnya, menghilangkan lilin malam dari kain tersebut dengan cara memasukkan kain tersebut ke dalam air panas diatas tungku. Setelah kain bersih dari lilin dan kering, dapat dilakukan kembali proses pembatikan dengan penutupan lilin (menggunakan alat canting)untuk menahan warna pertama dan kedua. Proses membuka dan menutup lilin malam tersebut dapat dilakukan berulangkali sesuai dengan banyaknya warna dan kompleksitas motif yang diinginkan.

Kemudian proses nglorod/dilorod, dimana kain yang telah berubah warna direbus air panas. Tujuannya adalah untuk menghilangkan lapisan lilin, sehingga motif yang telah digambar sebelumnya terlihat jelas. Pencelupan ini tidak akan membuat motif yang telah digambar terkena warna, karena bagian atas kain tersebut masih diselimuti lapisan tipis (lilin tidak sepenuhnya luntur). Setelah selesai, maka batik tersebut telah siap untuk digunakan. Proses terakhir adalah mencuci kain batik tersebut dan kemudian mengeringkannya dengan menjemurnya sebelum dapat digunakan dan dipakai.
Tempat menghilangkan lilin malam pada kain

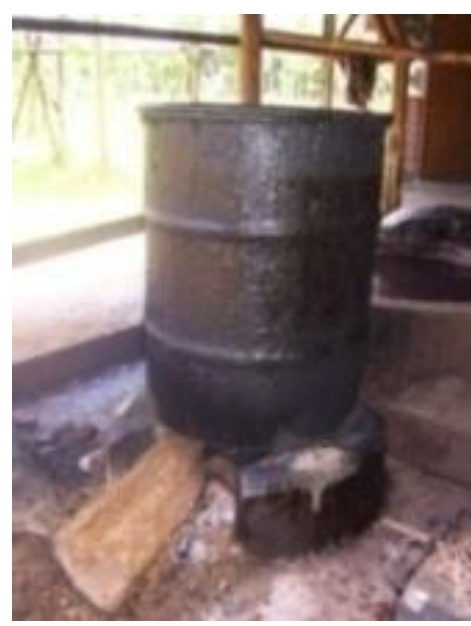

Tempat menjemur kain batik.

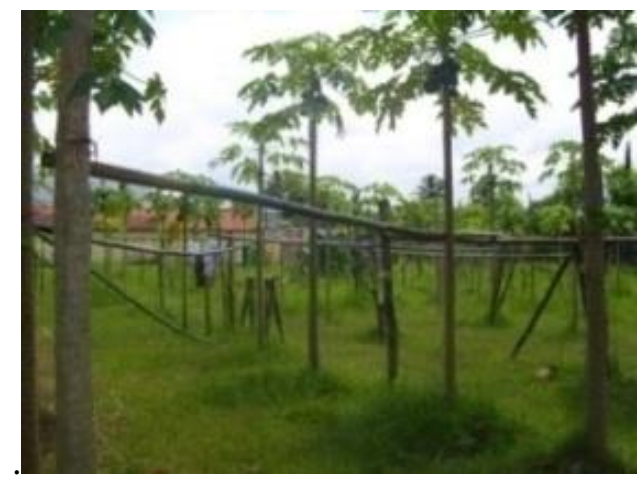

Sumber: Penelitian BPSNT Tahun 2011.

\section{Proses Pembuatan Batik Cap Ciamisan}

Batik cap dibuat dengan menggunakan cap, namun masih tetap menggunakan teknik batik (malam sebagai bahan perintang warna). Demikian,dalam pembuatan batik cap Ciamisan, bahan yang harus dipersiapkan pada dasarnya sama dengan yang digunakan dalam membatik tulis. Hanya peralatan dalam membatik cap menggunakan canting cap, kemudian meja dengan alas di bawahnya menggunakan bahan yang empuk, wadah yang cukup besarnya untuk merebus malam, dan kompor yang lebih besar (kompor gas). 
Canting cap, semacam stempel besar yang terbuat dari tembaga, yang sudah didisain dengan motif batik tertentu dengan dimensi $20 \mathrm{~cm}$ X $20 \mathrm{~cm}$. Selain dibentuk dari bahan dasar tembaga, ada pula yang dikombinasikan dengan besi. Dari jenis produksi batik cap ini, pembatik bisa menghemat tenaga, dan tak perlu menggambar pola atau disain di atas kain.

Berbagai motif cap.
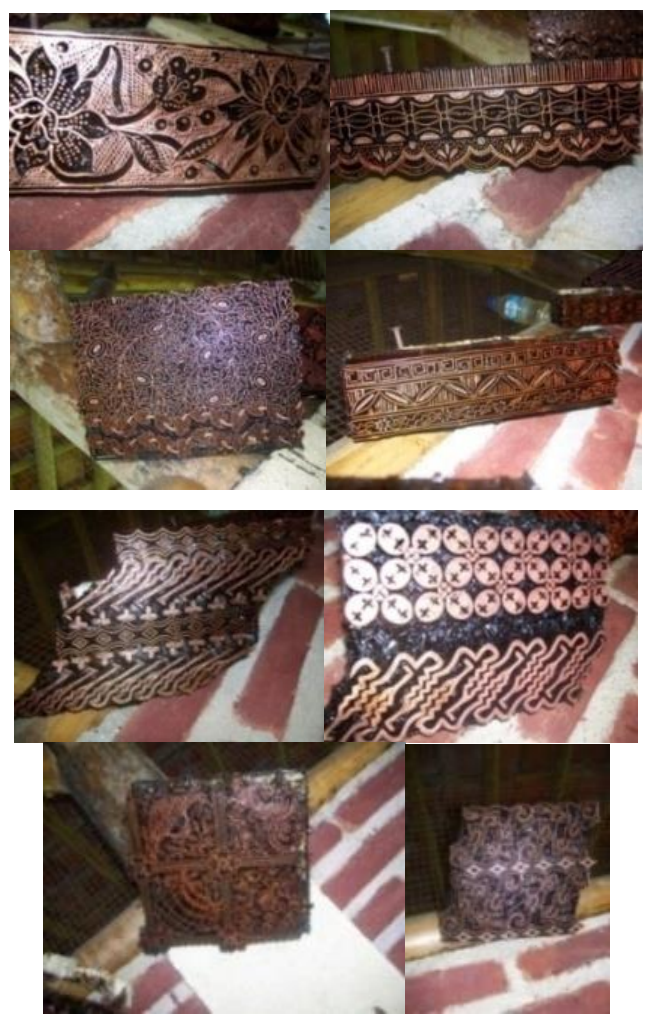

Sumber: Penelitian BPSNT Tahun 2011.

Berikut adalah proses pembuatan batik cap. Kain mori diletakkan di atas meja dengan alas di bawahnya menggunakan bahan yang empuk. Malam direbus hingga mencair (suhu $60^{\circ}-70^{\circ}$ Celsius) dancap dicelupkan ke dalamnya, tetapi hanya $2 \mathrm{~cm}$ saja dari bagian bawah cap. Kemudian kain mori dicap dengan tekanan yang cukup supaya rapih. Pada proses ini, cairan malam akan meresap ke dalam poripori kain mori. Proses berikutnya adalah proses pewarnaan dengan cara mencelupkan kain mori yang sudah dicap tadi ke dalam tangki yang berisi cairan pewarna.
Selanjutnya kain mori direbus supaya cairan malam yang menempel hilang dari kain. Demikian proses pengecapan $>$ pewarnaan>penggodogan diulangi kembali jika ingin diberikan kombinasi beberapa warna.Setelah itu, proses pembersihan dan pencerahan warna dengan menggunakan soda. Sebagai tahap akhir adalah penjemuran hingga kering, kemudian disetrika supaya rapih.

Malam dalam wajan sedang dicairkan di atas kompor gas

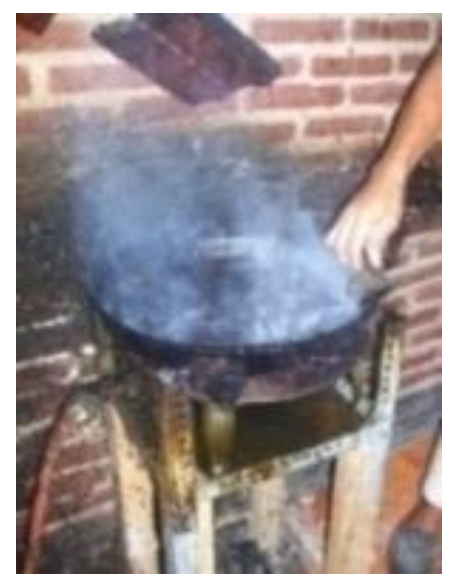

Proses pengecapan di atas kain mori

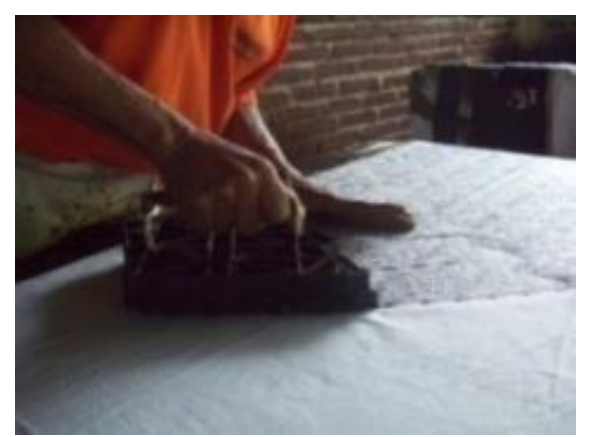

Proses pewarnaan pertama 


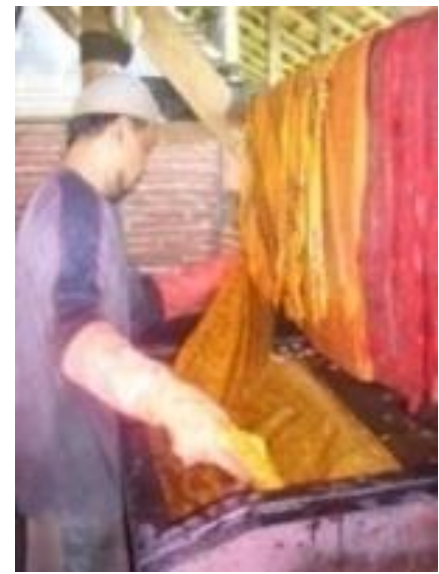

Sumber: Penelitian BPSNT Tahun 2011.

Proses pembuatan batik cap ini lebih cepat dibandingkan dengan proses pembuatan batik tulis karena pembuatan motifnya menggunakan cap (stempel) yang lebar. Bandingkan dengan batik tulis yang menggunakan guratan-guratan canting. Walaupun begitu, kedua jenis batik ini mempunyai keunikan tersendiri.

\section{Proses Pembuatan Batik Printing dan Pemasarannya}

Pembuatan batik printingdimulai dengan pemanasan dan pewarnaan kain pada suhu $160^{\circ}$ Celsius hingga $180^{\circ}$ Celsius. Kain putih dimasukkan ke mesin dan diberi warna dasar. Bila warna dasar yang diinginkan adalah putih, yang dilakukan adalah pemutihan kain.Pada proses batik ini, pola telah diprint di atas alat sablon, sehingga pembatikan dan pewarnaan biasa dilakukan secara langsung. Jadi, proses batik dapat diselesaikan tanpa menggunakan lilin malam serta canting. Dengan demikian, proses hanya akan dan tentu saja memerlukan waktu yang lebih cepat dibanding pada proses batik tulis dan batik cap.

Kain yang telah diwarnai tersebut dicetak dengan motif sesuai kebutuhan. Cetakannya dibuat dari klise. Pembuatan cetakan ini dilakukan dengan komputer. Kain yang telah bermotif selanjutnya dipanaskan kembali di mesin. Tahap ini untuk membangkitkan warna pada batik dan membuat tinta melekat kuat pada kain.
Setelah itu, kain batik dicuci. Tahap ini dalam bahasa Sunda disebut ngarorod. Kain batik yang telah bersih dikanji dan dipanaskan sampai kering. Tahap akhir adalah pemotongan, pengeliman, pelipatan, pemberian label, dan pengemasan. Kain batik pun siap dipasarkan ke daerahdaerah.

Pemasaran batik biasanya melalui jalur distribusi yang cukup panjang. Dari pabrik, pembeli dari Pasar Baru Bandung, misalnya, mengambil 100 kodi $(2.000$ potong) kain batik dengan truk. Barang dibawa ke Bandung baru dipasok ke daerah-daerah seperti Tasikmalaya, Garut, dan Cirebon.

Setiap hari produksi perusahaan ini sekitar 250 kodi (5.000 potong) kain batik. Setiap potong kain panjangnya 2,25 meter. Dengan harga jual Rp 15.000 untuk kain batik berbahan polyester dan Rp 30.000 untuk batik katun. Omzet Otong saat ini berkisar Rp 75 juta-Rp 150 juta per hari.

Secara kasat mata kita dapat membedakan batik print dan batik tulis/cap dengan melihat permukaan di balik kain, biasanya kain batik print warnanya tidak meresap ke seluruh serat kain, dan hanya menempel pada permukaan kain, sehingga di balik kain masih terlihat sedikit berwarna putih.

\section{PENUTUP}

Batik tulis Ciamisan terlahir sekitar abad ke-19, manakala masyarakat, khususnya kaum perempuan mendapat pengetahuan membatik dari para perempuan Yogyakarta yang turut serta merantau beserta keluarganya setelah selesainya peperangan Diponegoro. Para pengikut Diponegoro tersebut, saat itu meninggalkan Yogyakarta menuju ke selatan, salah satunya adalah daerah Ciamis.

Membatik adalah pekerjaan kerajinan rumah tangga bagi kaum perempuan di Yogyakarta, yang sebaliknya suatu hal yang asing bagi kaum perempuan di daerah Ciamis pada saat itu. Akibat pergaulan dengan para perempuan 
Yogyakarta tersebut, kemudian adanya kebutuhan sandang masyarakat - sandang berupa kain atau sinjang/samping untuk memenuhi kebutuhan sendiri, kaum perempuan Ciamis terinspirasi untuk belajar dan membuat batik sendiri.

Jadi dapat dikatakan, corak batik tulis Ciamisan tidak memiliki makna filosofi perlambang, nilai sakral, atau menunjukkan status sosial tertentu. Namun penciptaan motif atau ragam hias batiknya lebih ditekankan pada ungkapan kesederhanaan untuk memenuhi kebutuhan sandang, sinjang/samping 'kain' bagi masyarakat.

Filosofi kesederhanaannya itu terlihat dalam bentuk-bentuk motif yang terinspirasi dari alam sekitar dan kejadian sehari-hari, seperti motif rereng atau lereng yang menggambarkan tebing miring; kumeli, berupa empat bentuk yang mengelilingi pusat; cupat manggu, motif geometris bergambar buah manggis; daun rente dan daun kelapa, dua jenis tanaman yang akrab dalam kehidupan sehari-hari penduduk Ciamis dijadikan gambar ciri khas Ciamisan.

Beberapa motif lama batik Ciamisan lainnya yang telah terdata pengurus Sanggar dan Galeri Batik Koperasi Rukun Batik Ciamis, yaitu parang sontak,rereng seno, rereng sintung ageung, kopi pecah, lepean, rereng parang rusak, rereng adu manis, rereng parang ali, rereng useup, rereng jenggot, rereng peuteuy papangkuh, rereng suliga, dan rereng eneng.

Para pebatik dulu yang kembali aktif membatik, menghidupkan kembali tiga motif lama, yaitu motif parang sontak, galuh pakuan, dan suliga adumanis. Sementara itu tim kreatif Sanggar Batik Rukun Batik Ciamis dan Yayasan Batik Jawa Barat pun meluncurkan dua motif baru dengan slogan budaya Ciamis dan tempat wisata.Kedua motif baru batik Ciamisan era 2010 tersebut diberi nama motif Ciung Wanara dan motif Batu Hiu.

Sementara itu H. Otong Kartiman, penyelamat batik kembali menjalani usahanya dengan fokus utama pada batik cap dan printing untuk memenuhi permintaan konsumen; dan sesekali menerima pesanan batik tulis Ciamisan.

Kemudian upaya pelestarian batik tulis Ciamisan berlangsung dengan adanya sanggar pelatihan batik. Generasi muda tak hanya mengenal batik tulis Ciamisan dalam wujud jadi, juga dapat mempraktekkannya sendiri cara pembuatannya. Sehingga batik tulis Ciamisan sebagai aset kerajinan tradisional dapat bertahan bahkan berkembang dengan munculnya minat generasi muda untuk berusaha dalam perbatikan.

\section{DAFTAR SUMBER}

\section{Buku}

Hasanudin. 2001.

Batik Pesisiran - Melacak Pengaruh Etos Dagang Santri pada Ragam Hias Batik. Bandung: Kiblat.

\section{Internet}

Didit. 2008.

Batik Ciamis.

http://diditds.wordpress.com/2008/1 1/03/batik-ciamis/

Herlianto, Dudi. 2011.

[kisunda] Batik Ciamisan, Bersahaja

Tetapi Elegan.

M. Dani, Andri. 2009.

Menyusur Sisa Kejayaan Batik

Ciamisan. Minggu, 11 Januari

2009 | 15:54 WIB.Tribun Jabar.

Nur Arifah, Ema.

Hampir Punah, YBJB Angkat Batik

Ciamisan. Bandung : Detik.

Ramdhani, Dadan Hanial. 2009.

Sejarah yang Ada di Kabupaten

Ciamis, 14 Juni 2009.

Sawunggalih, Mustafid. 2009. 
Siapa Bilang Ciamis Tidak Mempunyai Batik?Batik Ditetapkan UNESCO Sebagai The World Cultural Heritage of Humanity from Indonesia. Mustafid Sawunggalih's picture. Mon, 10/05/2009 - 00:39.

Sudrajat, Undang /"PR". 2007a. 20 Corak Batik Tasikan Dipatenkan. "http://batiksunda.blogspot.com. 7 Juni 2007.

$.2007 \mathrm{~b}$

Otong Kartiman, Penyelamat Batik Ciamisan.

"http://batiksunda.blogspot.com. 7 Juni 2007

Sekarang, Parang Sontak Pun Penuh dengan Warna

Kamis, 12 Agustus 2010 | 13:51 WIB

Tribun Jabar.

Menyusur Sisa Kejayaan Batik Ciamisan.

http://www.tribunjabar.co.id/read/art ikel/4533/menyusur-sisa-kejayaanbatik-ciamisan

Bangkit Setelah 30 Tahun Terlelap (1)

Bahkan Mandor Godog Pun Turun Gunung

, TJ Online - Kamis, 12 Agustus $2010 \mid$ 13:47 WIB

Bangkit Setelah 30 Tahun Terlelap (2habis)

Sekarang, Parang Sontak Pun Penuh dengan Warna

> TJ Online - Kamis, 12 Agustus $2010 \mid$ 13:50 WIB

Batik.

http://id.wikipedia.org/wiki/Batik

Batik Ciamis Mulai Menggeliat Setelah Vakum 28 Tahun

PostDateIconThursday, 25 March 2010 11:50 | PostAuthorIconWritten by Administrator | PDF | Print | Email

Batik Sunda. 2007.

Penyelamat Terakhir Batik

Ciamisan.

http://batiksunda.blogspot.com/2007 /06/penyelamat-terakhir-batikciamisan.html 